\title{
RELATIONSHIP BETWEEN PERCEPTIONS OF FAMILY \\ LIFE AND ATTITUDES CONCERNING \\ FATHER-SON INTERACTION
}

\author{
By \\ DONNA BROWN GRAVES \\ Bachelor of Science \\ Oklahoma State University \\ Stillwater, Oklahoma
}

1969

Submitted to the Faculty of the Graduate College of the Oklahoma State University

in partial fulfillment of the requirements

for the Degree of

MASTER OF SCIENCE

July, 1971 : 
RELATIONSHIP BETWEEN PERCEPTIONS OF FAMILY

LIFE AND ATTITUDES CONCERNING

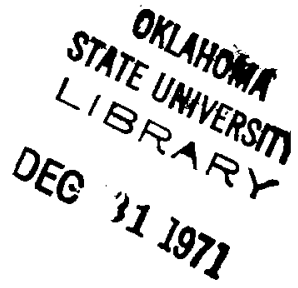

FATHER-SON INTERACTION

Thesis Approved:

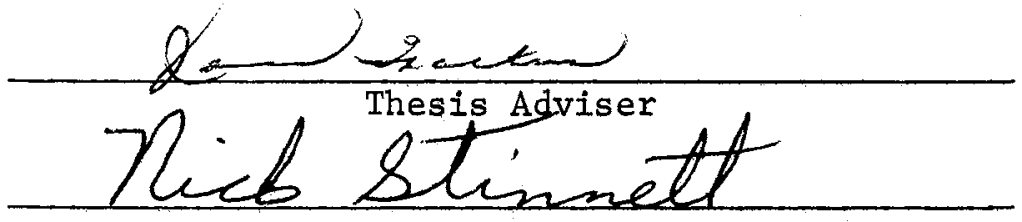

Peta $P$ ente

$\overbrace{\text { Dean of the Graduate college }}$ 


\section{ACKNOWLEDGMENTS}

The author would Ilke to express appreciation to Dr. James Walters, Professor, Family Relations and Child Development, for his continual enthusiasm and ençouragement given throughout the study. Recognition and apprectation are also extended to the following: Dr. Nick Stinnett, Associate Professor, Family Relations and Child Development, for his encouragement, suggestions, and critical reading of the manuscript; Dr. Ruth Pestle, Associate Professor of Home Economics Education, for her particlpation as a committee member; Mrs. Floye Ardrey, Assistant Professor of Family Relations and CHild Development and her students for their cooperation and enthusiastic participation In the study.

Spectal recognition is expressed to my husband, Toby, for his patience and encouragement and to our parents whose support and understanding have made the achievement of this goal a reality. 
TABLE OF CONTENTS

Chapter

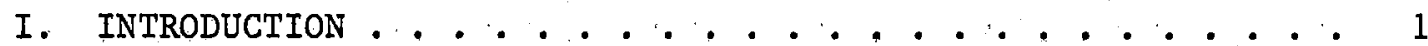

Purposes . . . . . . . . . . . . . 2

Hypotheses................... 2

II. REVIEW OF LITERATURE . . . . . . . . . . . . . 4

Relationships Between Parent and Child . . . . . 4

Types of Parental Control . . . . . . . . . 4

Authority and Discipline . . . . . . . . 5

Parental Influences According to Sex . . . . . 8

Parental Influences on Academic Achievement . . 9

Companion Relationship . . . . . . . . . . . 10

Fathers' Influence on Sons' Personality . . . . . . 10

Conflict . . . . . . . . . . . . . . 12

Factors Affecting Parent-Ch1ld Relationships . . . . 12

Soclal Class... . . . . . . . . . . 12

Age . . . . . . . . . . . . . . 13

III. PROCEDURE . . . . . . . . . . . . . . 14

Subjects . . . . . . . . . . . . . . . 14

Measurement of Permissive Attitudes Toward

Father-Son Interaction . . . . . . . . . . . 14

Description of the Instrument . . . . . . . . . 14

Measurement of Perceptions Concerning

Family of Orientation ... . . . . . . . . . 19

Administration .............. . . 20

Analysis of Data ............... 21

IV. RESULTS . . . . . . . . . . . . . . . 22

Home Life Scale . . . . . . . . . . . . 22

The Item Analysis: . . . . . . . . . . 22

Relationships Between Scores and

Selected Background Variables.......... 35

Responses to the Home Iffe Scale . . . . . . . 35

V. SUMMARY AND IMPLICATIONS .. . . . . . . . . . . . 40

Implications .................. . 4 41

BIBLIOGRAPHY . . . . . . . . . . . . . . . . . . . 44 
APPENDIX A - THE EATHER-SON INTERACTION TEST APPENDIX B - STOTT'S HOME LIFE SCALE . . . . . . . . . . 55 APPENDIX C - KEY FOR THE STOTT'S HOME LIFE SCALE . . . . . . . . 61 APPENDIX D - INFORMATION SHEET . . . . . . . . . . 64 


\section{LIST OF TABLES}

Table

Page

I. Characteristics of the subjects . . . . . . . . 15

II. Discriminating Items on the Home Life Scale . . . . . 23

III. Responses of University Men to the Home Life Scale . . . . . . . . . . . . . 29

IV. Mann-Whitney U Analysis of Home Life Scale Scores Classified by Selected Background Varlables . . . . . . . . . . . 35

V. Kruskal-Wallis Analysis of Home Life Scale Scores Classifled by Selected Background Varlables . . . 36

VI. Mann-Whitney U Analysis of Eather-Son Interaction Test Scores Classifled by Selected Background Varlables . . . . . . . . . . . 37

VII. Kruskal-Wallis Analysis of Father-Son Interaction Test Scores Classified by Selected Background Variables ... . . . . . . . . . 38

VIII. Spearman $r$ Analysis of Father-Son Interaction Test and the Home Life Scale . . . . . . . . . . 39 
CHAPTER I

INTRODUCTION

Although considerable investigation has been made of the impact which mothers have on chlldren, relatively little study has been made of the impact of fathers on children. However, the investigations which have been done suggest that the Impact which fathers have may actually be greater than that of mothers (Walters and Stinnett, 1971).

The Importance of fathers was emphasized by Sopchak (1952) who found that in both men and women the failure to identify with their fathers was more closely associated with tendencles toward abnormality than failure to identify with their mothers.

The need for more research on the father-child relationship is growing as the man begins to assume increasing responstbility for child rearing. Ostrovsky (1959) suggests that male participation in childrearing should be increased and that Inadequate male influence involves the danger of limiting and inhibiting the child's emotional growth.

A review of the literature (Benson, 1968) suggests that the child should be adequately exposed to male as well as female influence. In the average family where both parents are present, ch 11 d-rearing methods, combining the love and warmth of the family with the proper degree of restrictiveness or permissiveness, have proved to be extremely important.

A detailed review of the literature on fatherhood by Benson (1968) 
emphasizes the importance of the role of the father in the socialization of children but the factors responsible for differences in attitudes among men concerning chlldren and youth are not clear.

\section{Purposes}

The present research was designed to:

1. Develop a form of the Home Life Scale (Stott, 1956) for unfversity men; an instrument which provides a measure of the subject's perceptions of their home life in their families of orlentation.

2. Examine the perceptions of men concerning their home, life in relation to their attitudes concerning father-son relationships and selected background characteristics.

Hypotheses

The hypotheses examined in the study were:

1. There is no significant relationship between perceptions of university men concerning the home life which existed in their famllies of orientation and:
(a) age
(b) marital status of student
(c) father's occupation
(d) father's education
(e) source of family income
(f) socio-economic status of parents

2. There is no significant relationship between attitudes of university men concerning father-son relationships and 

(a) age
(b) marital status of students
(c) father's occupation
(d) father's education
(e) source of family income
(f) socio-economic status of parents

3. There is no significant relationship between attitudes of university men concerning father-son relationships and their perceptions concerning the home life which existed in their families of orientation. 


\section{REVIEW OF - LITERATURE}

Although there have been radical changes in the American pattern of family life, the family remains the most significant part of the child's social network (Clark and Sommers, 1961). Hurlock (1964) points out that the home is, normally, the child's first environment and usually sets the pattern for the child's attitude toward people, things, and life in general. Because the child often Identifies with the family members he loves, he imitates their patterns of behavior and learns to adjust to life as they adjust (Koppitz, 1957).

\section{Relationships Between Parent and Child}

\section{Types of Parental Control}

Parental control can be divided into three levels. Many authors have attempted to describe, define, and characterize these levels. Baumrind (1966) has termed the levels permissive, authoritative, and authoritarian. She has given the following definitions for these three types of parental controls. The permissive parent is defined as one who:

attempts to behave in a nonpunitive, acceptant; and affirmative manner toward the child's impulses, desires, and actions. . allows the child to regulate his own activities as much as possible, avoids the exercise of control and does not encourage h1m to obey externally defined standards ( $p .889$ ). 
The authoritative parent is defined as one who:

attempts to direct the child's activities in a rational, issue-oriented manner. . encourages verbal give and take, shares with the child the reasoning behind her policy, and solfcits his obfections when he refuses to conform. Both autonomous selfw11l and disciplined conformity are valued... exerts firm control at points of parent-child divergence, but does not hem the child in with restrictions .. . uses reason, power, and shaping by regime and reinforcement. (p. 891).

The authoritarian parent is defined as one who:

attempts to shape, control, and evaluate the behavior and attitudes of the child in accordance with a set standard of conduct, usually an absolute standard theologically motivated and formulated by a higher authority. . . values obedience as a virtue and favors punitive, forceful measures to curb self-will at points where the child's actions or beliefs conflict with what she thinks is the right conduct . . does not encourage verbal give and take, believing that the child should accept her word for what is right ( $p .890$ ).

\section{Authority and Discipline}

In the American family much of the authorfty and discipline has been transferred to the mother because of the father's absence during the day. Many fathers belleve, however, that they should assume more authority in their children's disclpline. Tasch (1952) found, in her study, that the concept of father as "head of the house" was given support. Strecker (1946) also points out the need for paternal authority, belleving that too much maternal domination will have deleterlous effects in terms of the roles which men assume. Bossard and Boll (1960) support'strecker's findings, writing that "certain doctors, clergymen, and social scientists agree that paternal authority should be maintained to a considerable extent for the health of the family relationships and the development of the children." 
The type of discipline used by mother and father often differs. Mothers tend to incorporate "moral controls." Moral controls refer to the ability to get the child to adopt a set of values by which to govern himself, independent of external threats or regulations. On the other hand, fathers more often use a "jural control" form of discipline. The jural control discipline consists of enforcing a set of rules. These jural controls make clear to the child that there are rules to be obeyed, whether he likes it or not (Nunn, 1964; Martin and Clark, 1966). There is even a difference between father and mother in what they discipline for. Fathers stress conformity (jural control); they strive to have their children act like other children and are more alarmed if they are unusual in any way (Nunn, 1964; Tallman, 1965).

A third source of "child management," operating independently of jural and moral discipline, consists of "identification controls." The child develops appropriate: "self controls" more through identification with his parents than in response to the disciplinary actions they use. The most effective paternal identification is characterized with expressive warmth between father and child. "Love and affection" are encouraged because they are believed to foster a willingness to cooperate in children (Hoffman, 1963).

The parent who uses severe punishment to control the aggressive actions of boys succeeds in curtailing them only in the presence of the parent. Lefkowitz, Walder and Eron (1963) found that when boys are punished severely, the frustrating effect of the punishment seems to overcome the inhibiting effect, and they become more aggressive than. they would otherwise be. Temperate punishment, carefully designed to the problem at hand, is much more effective in the long run (Benson, 1968). 
Delaney (1965), in a study of parental antecedents of social aggression in young children, found that parental restrictiveness was positively related to child aggression especially in boys. Early control by parents when accompanied with warmth does not, like extreme punitiveness and restrictiveness, lead to fearful, dependent, submissive behavior (Baumrind, 1967). Clapp (1967) concurs with this finding. In his study of four-year-old boys it was found that parents of competent children (as contrasted with dependent children) treated their sons more as a child and less like an adult. It was also found that the parents of the competent children were significantly more permissive, less restrictive, warmer and less hostile.

A study of the relationship between type of punishment used by parents and aggression and identification in eight-year-old children showed that aggression in children increases as parents increasingly rely upon physical punishment for controlling the child's behavior (Lefkowitz, Walder, and Eron, 1963).

Starr (1965) found significant positive relationships between children's authoritarianism and strict parental discipline with the strongest relationships between the children's authoritarianism and the discipline attitudes of the parents of the opposite sex.

Children who experience responsibility as external to themselves usually have parents who entirely exercise power controls (Lang, 1969). Miller and Swanson (1960) suggest that "love oriented" techniques of child-rearing seem to contribute to the development of guilt feelings in the child, while physical punishment, withdrawal of privileges and threats tend to contribute to overt aggression. In families where the children exercise power, the children seem to be preoccupied with their 
own needs and remain indifferent to the deep needs of others. Shared power by both parent and child enables the child to experience the locus of responsibility as within himself and thus he becomes responsive to the needs of others. Anarchy tends to limit children to indifference or inability to respond to others (Lang, 1969).

\section{Parental Influences According to Sex}

The theory that boys are more susceptible than girls to parental Influence has often been used to explain the higher frequency of schizophrenia, delinquency, stuttering, and reading and behavior problems in boys (Medinnus, 1967). In a study of the relationship between adjustment in a group of adolescents and their perceptions of their parents, Medinnus (1965) found that there was a closer relationship between adjustment and perceptions of parents among boys than among girls. Bayley (1965) found higher correlations between ratings of maternal behavior from birth to three years and intelligence for boys than for girls. The effects of maternal behavior on intelligence is greater for boys than for girls. Early maternal behavior showed a persistent relationship to certain aspects of adolescent behavior for boys but not for girls (Schaefer and Bayley, 1963).

In a study concerning parent-child relationships of 10 th grade adolescents, Bronfenbrenner (1961) found that girls were especially likely to be over-protected, while boys, on the other hand, were much more likely to reap the $i 11$ effects of parental discipline and support. Bronfenbrenner suggests that these differences in influence are the result of aspirations which parents have for their children. Independence, initiative, and self-sufficiency are highly valued for boys and 
require a different amount of authority and affection than the "loved" discipline often utilized with girls.

Parental Influences on Academic Achievement

Walters and Stinnett (1971) in a decade review of the literature, found that academic achievement, creative thinking, and leadership in children was "positively related to warm, accepting, understanding, and autonomy-granting parent-child relationships." Parents of over achievers tended to show a greater understanding of their children (Peppin, 1963). The results of this study by Peppin indicated that the parents of over achievers were, to a slgnificant degree, more accepting of their children than were parents of under achievers.

The effects of parent-child relations are strong and continue to influence the young adult in college. In a study by Cross and Allen (1969) the memorles of parental behavior were related to academic achievement in college. The results indicated that "benevolent autonomy-granting patterns of parental behavior are related to the offspring's superior academic achievement."

For high school boys; there tends to be a positive relationship between academic achlevement and the perception that parents valued academic achievement (Christopher, 1967). In addition, Norris (1968) found that satisfaction and parental understanding of the child was positively related to the child's achievement of basic skills, school grades, and favorable teachers' comments for pre-adolescent boys. Granlund and Knowles (1969), when studying the relationship between masculine ident1fication in male students and academic under achievement, found that the "under achievers had a significantly lower masculine identification 
than did the students who were classified as achievers."

Companion Relationship

Differing from the authority relationship between father and child is the idea that the father must be a companion to the child. Bossard and Boll. (1960) find this true particularly with a father-son relationship. According to Hurlock (1964), fathers of middle and upper classes emphasize understanding the child, being a companion, and guiding the child's development. The father who believes in these concepts of his role demonstrates a use of democratic forms of control over his children, attempting to avoid harsh punishment and helping his child prepare for a future in keeping with his abilities. On the other hand, Wylie (1955) is critical of fathers and reports an experiment by Gordon Schroeder where three hundred seventh- and eighth-grade boys kept an accurate record for two weeks of the time fathers spent with their son. The mean was seven and one half minutes per week, suggesting that sons percelved that their fathers spent relatively little time with them. Bartemeier (1953) writes that

Because the father is traditionally authoritarian in his attitudes toward the child, the man who loves his sons is often considered 'soft and unmasculine.' Therefore, to conform to social ideals, the father becomes strict and harsh in his treatment of his sons; by so doing, he is likely to make bullies out of them.

\section{Father's Influence on Son's Personality}

That the roles which fathers assume are of significance is illustrated in the studies which indicate that male children reared in homes where the father is harsh, punitive, or demanding frequently produce 
sons who are neurotic (Mckeown and Lhyatte, 1954), and show more femintne interests (Mussen, 1961). The homes where the father is weak or ineffectual have sons who have difficulty in establishing masculine interests and not infrequently become homosexual (Biller, 1968). In contrast, sons reared in homes where the father is warm and affectionate show strong masculine interests (Mussen, 1961; Biller and Borstelmann, 1967), and Identify with their fathers (Sears, 1953; Payne and Mussen, 1956).

Benson (1968) believes that what we learn from our parents tends to become ritualistic and dogmatic and that parents program the subconscious behavior and attitudes of the child. By comparison, what is learned from others is received in more of a pragmatic way, leaving the individual freer to pick what is useful to his needs and to ignore the rest. The parental imprint is indelible, although the values of the father, In the process of transmission to his sons, may be transformed into something quite different from what the father had in mind (Inkeles, 1963; Elder, 1964).

Because father is in the strategic position of decision maker in areas which vitally affect his children, he serves as teacher, censor, and promoter. Benson (1968) suggests that mother's interests and expertise are typically restricted to household activities and matters of everyday routine; father can deal with "global" problems of purpose and has a broader perspective on the balance between cosmopolitanism and provinclalism. 
$\underline{\text { Conflict }}$

Almost all available evidence indicates that children have greater conflict with the father than the mother and they consistently perceive their mothers more favorably (Hawkes, 1957). Becker and Krug (1964) found that the tendency is to look upon father as the "principal generator of fear." Among college students, Rose (1959) found that both men and women had a greater willingness to express fondness for mothers than for fathers. The conflict with father usually damages his image more than conflict with mother can damage hers (Benson, 1968). Conflict with father follows a pattern that is difficult to arrest, often leading to a viclous rather than a beneficent cycle in parent-child relations (Hallowitz and Stulberg, 1959).

Fathers have more conflict with sons than daughters because girls accept authority more readily than boys do (Koch, 1955). Tuma and Livson (1960) concur, finding girls to be more compliant to authority than boys. Therefore, psychological discipline is most effective in establishing moral codes for both sexes, especially for sons (Johnson, 1963).

The most intense period of conflict seems to come in the first stages of adolescense. Benson (1968) contends that the toughest period for parent-child conflict usually occurs in the first years of adolescence.

\section{Factors Affecting Parent-Child Relationships}

Social Class

Basic differences exist in parent-child relationships according to social class which reflect different living conditions. Middle class 
boys more often evaluate their parents as successful, smart, ambitious and secure than do lower-class boys (Rosen, 1964). He also suggests that middle-class boys perceived a greater degree of parental acceptance, interest, and support than did lower-class boys.

Middle-class parents tend to be more controlling and supportive of their chlldren than lower-class parents and the middle-class parents are more likely to discipline thelr children by utilizing reasons and appeals to guilt and are less likely to use physical punishment (Walters and Stinnett, 1971).

Age

In studying the effects of sexual maturing on boys, Sollenberger (1940) observed several significant differences between boys at different levels of maturation. Mature boys were interested in real things and real people whereas immature boys were interested in imaginary phenomena.

Stone and Barker (1937) indicated important differences between responses of mature and immature girls in their study of 1,000 pre- and postmenarcheal girls. There was little evidence in their study to show that mature girls engaged in family friction or revolted against family discipline any more than the immature girls. 
CHAP TER III

P ROCEDURE

Subjects

The subjects for this study were college males at Oklahoma State University enrolled in the course Home Economics for Men. A total of 108 students comprised the sample. The majority of the students ranged in age from seventeen to twenty-five. A description of the students is presented in Table $I$.

\section{Measurement of Permissive Attitudes Toward} Father-Son Interaction

\section{Description of the Instrument}

The Father-Son Interaction Test, a filmed instrument was used to measure permissive attitudes related to father-son interaction. The instrument consists of eleven scenes, each of which is about one minute in length. These scenes include a wide variety of themes in which father and son interact. The same characters play father and son throughout the film and are the only characters in ten of the eleven scenes. Although Scene VIII involves other actors, the father and son are the primary characters.

In the original film, Doyle (1968) developed twelve scenes; however, eleven were selected and used in the completed film instrument. The eleven scenes utilized were selected according to the following 
TABLE I

CHARACTERISTICS OF THE SUBJECTS

\begin{tabular}{|c|c|c|}
\hline Description & $\mathrm{N}$ & $\%$ \\
\hline \multicolumn{3}{|l|}{ Age } \\
\hline $\begin{array}{l}\text { Under } 20 \\
20-24 \\
25 \text { and Over }\end{array}$ & $\begin{array}{r}48 \\
51 \\
9\end{array}$ & $\begin{array}{r}44.44 \\
47.22 \\
8.33\end{array}$ \\
\hline \multicolumn{3}{|l|}{ College Major } \\
\hline $\begin{array}{l}\text { Agriculture } \\
\text { Arts and Sciences } \\
\text { Business } \\
\text { Education } \\
\text { Home Economics } \\
\text { Technical School } \\
\text { Undecided }\end{array}$ & $\begin{array}{r}9 \\
20 \\
52 \\
6 \\
2 \\
4 \\
15\end{array}$ & $\begin{array}{r}8.33 \\
18.52 \\
48.15 \\
5.56 \\
1.85 \\
3.70 \\
13.88\end{array}$ \\
\hline \multicolumn{3}{|l|}{ Marital Status } \\
\hline $\begin{array}{l}\text { Single } \\
\text { Married }\end{array}$ & $\begin{array}{l}89 \\
19\end{array}$ & $\begin{array}{l}82.41 \\
17.59\end{array}$ \\
\hline \multicolumn{3}{|l|}{ Socioeconomic Status } \\
\hline $\begin{array}{l}\text { Upper and Upper-Middle Class } \\
\text { Middle and Lower-Middle Class } \\
\text { Upper-Lower and Lower-Lower Class }\end{array}$ & $\begin{array}{l}45 \\
39 \\
24\end{array}$ & $\begin{array}{l}41.66 \\
36.11 \\
22.22\end{array}$ \\
\hline \multicolumn{3}{|l|}{ Father's Education } \\
\hline $\begin{array}{l}\text { Over } 4 \text { years College } \\
\text { College Graduate } \\
1-3 \text { Years College } \\
\text { High School Graduate } \\
\text { Grades } 9-11 \text { Completed } \\
\text { Grade } 8 \text { Completed } \\
\text { Below } 8\end{array}$ & $\begin{array}{r}14 \\
18 \\
15 \\
40 \\
13 \\
7 \\
1\end{array}$ & $\begin{array}{r}12.96 \\
16.66 \\
13.88 \\
37.04 \\
12.04 \\
6.48 \\
0.93\end{array}$ \\
\hline
\end{tabular}


criteria:

1. Physical properties. Clarity of subjects, correct film exposure and lighting, and audible sound were considered essential in the selection of the scenes.

2. Behavioral patterns. The filmed action clearly depicted specific types of behavior in each of the scenes.

3. Theme diversity. Each scene presented portrayed different concepts of family life such as responsibility, ego involvement, and pride which related to the concept of permissive attitudes in father-son relationships.

4. Objectivity. In each scene, no extraneous variables were obvious enough to distract from the primary purpose of that scene.

The following is a description of each of the eleven scenes.

Scene I. The father enters the son's bedroom to awaken him. He calls several times but the son moans and turns over. The son finally reluctantly sits up on the side of the bed.

Scene II. The father is reading the morning newspaper when the son enters the room to ask for his allowance. The father ignores his son's request.

Scene III. Father and son are eating lunch together and have to leave home at the same time. While relating the details of his weekend trip to the beach, the son does not eat his meal. When it is time for both of them to leave, the father realizes that the son has not even begun to eat. 
Scene IV. After the baseball game, the son rushes up to his father pleased that his team had won and that he had made the winning run. The father responds by asking, "What about that 'pop-up fly' you missed?

Scene $V$. The father has forgotten a previous promise to play golf with his son and has made a date with his friend to play golf instead. The scene ends when the father says, "Well, I guess I could call Fred?"

Scene VI. The son has been told that he is to rake the leaves in the yard. He is reluctant and protests that he is tired. The father insists that the lawn should be raked today.

Scene VII. Father and son are in the dining room waiting for dinner. The son reaches for a mint on the table and accidently turns over a glass of water. The father starts toward the kitchen to get a rag to clean up the water.

Scene VIII. While eating dinner, guests and family are discussing some of the problems which pertain to school and education. The father asks the son what his opinion of the situation is. The son does not respond.

Scene IX. The father enters the son's bedroom and finds him watching television instead of doing his homework. When confronted with the question as to "why?" the son complains that he does not know what the teacher wants. The father takes the notebook and begins to work out the problems for his son.

Scene $\underline{x}$. The father is waiting for a business telephone call when the phone rings for the son. The father hands him the phone and tells 
him not to talk over two minutes. The son talks longer than his time limit.

Scene XI. The father enters the son's bedroom and finds him hanging a "pinup" picture of a woman on his wall. The son is surprised at the entrance of his father. The father says, "What's going on in here?" After viewing each scene, the subjects recorded their reactions to a highly structured set of items (Appendix A) which allowed for a latitude of reactions and contained four-point scales reflecting permissive attitudes toward father-son interaction.

The scale items were originally developed by Doyle (1968) and were rated and judged for validity by a panel composed of specialists in child development, psychology, and home and family life. An original pool of 180 items was submitted to the judges, who rated each item in terms of the following criteria:

1. Does the item possess sufficient clarity?

2. Is the item suficiently specific?

3. Is the item significantly related to the concept under investigation?

The final selection of the 134 items was based on the decision of the judges, and as a result of an item analysis.

A chi square test was used to determine which items on the FatherSon Interaction Test discriminated high and low scoring students in a study by Heath (1970); that is, which items elicited significantly different responses from those students whose total scores fell in the upper quartile and the lower quartile. Utilizing 148 respondents, 94 of the 134 items developed by Doyle were found to be significant at the .05 level or beyond. It is Heath's version of the test, designed 
especially for male university students, which was utilized in the present investigation.

\section{Measurement of Perceptions Concerning}

Family of Orientation

To obtain a measure of the subjects' perceptions of their home life, in the1r family of orientation, the Home Life Scale (Stott, 1956) was used. The present 80 -item edition of the instrument which yields a measure of the individual's perception of confidence, affection, and companionability of his family life is based on a synomization method analysis of responses of 490 youths, $13-20$ years of age, to 150 items.

The synomization process consists simply in the determination of the degree to which a "key item" is correlated with every other item on the questionnaire. For example, the response "Frequently" to the key item selected, "When your personal affairs are concerned, do you think: "What my folks don't know won't hurt them" was believed by Stott and his associates to indicate a lack of mutual confidence between the youngster and his parent, and the answer "Rarely" indicated a closeness of relationship. Subjects repond to the items on the scale in terms of "Frequently", "Occasiona1ly", or "Rarely." Percentage differences were used to record these differences (Stott, 1956).

A percentage difference at least three times the standard error was taken to indicate a significant degree of correlation in Stott's study. Any item significantly related to either positive or the negative response to the key item was regarded as having meaning in common with the key item.

In order to obtain an index of the usefulness of Stott's items for a group of male university students, an item analysis was undertaken 
using a chi square technique. Total scores were obtained on the Home Life Scale with weights being assigned as follows: The most desirable response recelved a weight of two, the second most desirable response recelved a weight of one, and the least desirable response received a weight of zero. Scores obtained were ranked from the most desirable to the least desirable, and were divided into quartiles. A chi square analysis was employed to determine those items which discriminate the high and low scorers (those whose total score fell in the upper quartile and those whose total scores fell in the lower quartile). Those items which attained a level of significance at the .05 level or beyond were retained in the final instrument.

The wording of the Home Life Scale was adapted thusly: from "Is meal time a happy time in your family?" to "Was meal time a happy time in your family?"

In order to assess the reliability of the instrument, a split-half technique was employed, utilizing a Spearman $r$.

\section{Administration}

The admintstration of the Father-Son Interaction Test took place during the regular class session of Home Economics for Men at Oklahoma State University. Each scene was shown individually and time was allowed for the subjects to respond to an item pool consisting of 94 items. The items pertaining to each individual scene were answered immediately after viewing the particular scene. A sample instrument is presented in Appendix A.

The Stott's Home Life Scale was given out at the end of the regular class session after the students had completed the Father-Son Inter- 
action Test. The Home Life Scale was to be completed at home and returned at the next class period.

Information concerning personal background, socloeconomic status, and family history of the subjects was obtained. Questions related to socioeconomic status were based on the McGuire-White Index of Soctal Status (Short Form) (1955). A sample information sheet is presented in Appendix D.

\section{Analysis of the Data}

The Spearman $r$ correlation coefficient was used to determine the reliability of the Stott's Home Life Scale after its revision to make it applicable for unfversity men. The Mann-Whitney U test was used whenever comparisons were made utllizing two independent samples. The Kruskal-Wallis one-way analysis of variance was used whenever comparisons were made ut 11 zing three or more samples in order to obtain a measure of the significance of the differences observed. 
CHAPTER IV

RESULTS

$\underline{\text { Home }} \underline{\text { Life }} \underline{\text { Scale }}$

The I tem Analysis

A chi square test was used to determine which items on the Stott's Home Life Scale (revised form for male university students) were discriminating, that is which items elicited significantly different responses between those subjects whose total score fell in the lower quartile and those subjects whose total score fell in the upper quartile. Of the 80 items initially included, 72 , or 90 percent, were found to be significantly discriminating at the .05 level or beyond. The total score for each subject, which was compared to the score on the Father-Son Interaction Test and the background variables of the subjects, was based upon the discriminating items only. The results of the item analysis are presented in Table II.

In order to assess the reliability of the instrument, a split-half technique was utilized. A.Spearman $r$ of .90 was obtained. By using the Spearman-Brown correction factor, a .94 reliability was obtained. These indications of consistency suggest that the revised edition of the Home Life Scale for university men is of sufficient reliability to warrant its use in the kind of study reported herein. 
TABLE II

DISCRIMINATING ITEMS ON THE HOME LIFE SCALE

\begin{tabular}{|c|c|c|c|}
\hline & I tem & $x^{2}$ & $\begin{array}{c}\text { Level of } \\
\text { Significance }\end{array}$ \\
\hline 1. & Was meal time a happy time in your family? & 23.41 & .001 \\
\hline 2. & Do the members of your family enjoy hobbies? & 2.38 & n.s. \\
\hline 3. & Are birthdays special days in your family? & 10.88 & .05 \\
\hline 4. & $\begin{array}{l}\text { Did your father attend the school programs } \\
\text { and other school activities in which you } \\
\text { took part? }\end{array}$ & 9.61 & .05 \\
\hline 5. & Was your family breakfast a gloomy affair? & 11.76 & .01 \\
\hline 6. & Was your father a good sport? & 25.32 & .001 \\
\hline & Was your mother a good sport? & 10.89 & .01 \\
\hline 8. & $\begin{array}{l}\text { Did it seem as if your family treated you } \\
\text { like a child? }\end{array}$ & 20.88 & .001 \\
\hline 9. & $\begin{array}{l}\text { Did your family talk over future plans } \\
\text { together? }\end{array}$ & 22.32 & .001 \\
\hline 10 . & $\begin{array}{l}\text { Did your parents listen to your side when } \\
\text { you disagreed with them? }\end{array}$ & 18.46 & .001 \\
\hline 11. & $\begin{array}{l}\text { Did your parents ever admit they had been } \\
\text { wrong? }\end{array}$ & 8.66 & .05 \\
\hline 12. & Did you "talk back" to your father? & 7.91 & .05 \\
\hline 13. & Did you "talk back" to your mother? & 13.05 & .01 \\
\hline 14. & $\begin{array}{l}\text { Did your parents stay home because they } \\
\text { had so much work to do? }\end{array}$ & 2.14 & n.s. \\
\hline 15. & $\begin{array}{l}\text { Did you leave the place without telling } \\
\text { anyone where you were going? }\end{array}$ & 2.35 & n.s. \\
\hline 16. & $\begin{array}{l}\text { Did you hesitate to talk frankly with your } \\
\text { father about personal problems? }\end{array}$ & 25.76 & .001 \\
\hline 17. & $\begin{array}{l}\text { Did you like to do extra little things to } \\
\text { please the members of your family? }\end{array}$ & 9.33 & .01 \\
\hline
\end{tabular}


TABLE II (CONTINUED)

\begin{tabular}{|c|c|c|c|}
\hline & Item & $x^{2}$ & $\begin{array}{l}\text { Level of } \\
\text { Significance }\end{array}$ \\
\hline 18. & $\begin{array}{l}\text { Would you have been more proud of your } \\
\text { father if he had changed some of his ways? }\end{array}$ & 20.89 & .001 \\
\hline 19. & $\begin{array}{l}\text { Would you have been more proud of your mother } \\
\text { if she would have changed some of her ways? }\end{array}$ & 10.96 & .01 \\
\hline 20. & $\begin{array}{l}\text { Did your mother like to listen to what you } \\
\text { told her when you got home from school? }\end{array}$ & 16.19 & .001 \\
\hline 21. & $\begin{array}{l}\text { Did your father resent it when you dis- } \\
\text { agreed with him? }\end{array}$ & 21.62 & .001 \\
\hline 22. & $\begin{array}{l}\text { Did your mother resent it when you dis- } \\
\text { agreed with her? }\end{array}$ & 18.19 & .001 \\
\hline 23. & $\begin{array}{l}\text { Did you have "a say" as to how and where } \\
\text { the family spent its holidays? }\end{array}$ & 17.40 & .001 \\
\hline 24. & $\begin{array}{l}\text { Did you think "Oh what is the use!" after } \\
\text { you had tried to explain your conduct to } \\
\text { your parents? }\end{array}$ & 24.80 & .001 \\
\hline 25. & $\begin{array}{l}\text { Did you think your mother gave pretty } \\
\text { sound advice? }\end{array}$ & 4.08 & .05 \\
\hline 26. & $\begin{array}{l}\text { Did you think your father gave pretty } \\
\text { sound advice? }\end{array}$ & 20.03 & .001 \\
\hline 27. & Did you try out what your parents advised? & 8.47 & .05 \\
\hline 28. & $\begin{array}{l}\text { Did you turn down: chances to go out with } \\
\text { others in order to keep your appointment } \\
\text { to do something with your family? }\end{array}$ & 6.88 & .05 \\
\hline 29. & Did you feel that your mother liked you? & 5.70 & n.s. \\
\hline 30 . & Did you feel that your father liked you? & 14.30 & .001 \\
\hline 31. & $\begin{array}{l}\text { When you went to another town, did you buy } \\
\text { souvenirs or gifts for persons in your } \\
\text { family? }\end{array}$ & 14.30 & .001 \\
\hline 32 . & $\begin{array}{l}\text { Did either of your parents read your per- } \\
\text { sonal mail without your permission? }\end{array}$ & 9.93 & .01 \\
\hline 33. & $\begin{array}{l}\text { Did you let your parents in on your "big } \\
\text { moments? }\end{array}$ & 12.81 & .01 \\
\hline
\end{tabular}


TABLE II (CONTINUED)

\begin{tabular}{|c|c|c|c|}
\hline & Item & $x^{2}$ & $\begin{array}{l}\text { Level of } \\
\text { Significance }\end{array}$ \\
\hline 34. & Did you feel rebellious around your family? & 26.36 & .001 \\
\hline 35 . & $\begin{array}{l}\text { Did you get your information on sex from } \\
\text { your parents? }\end{array}$ & 16.08 & .001 \\
\hline 36. & $\begin{array}{l}\text { Was your father too busy to pay any atten- } \\
\text { tion to the family? }\end{array}$ & $: 15.48$ & .001 \\
\hline 37. & Did you think your family picked on you? & 24.28 & .001 \\
\hline 38 . & $\begin{array}{l}\text { Did you enjoy being shut in with your } \\
\text { family on a stormy day? }\end{array}$ & 15.84 & .001 \\
\hline 39 . & $\begin{array}{l}\text { Did your parents trust you to behave when } \\
\text { you were away from them? }\end{array}$ & 9.71 & .01 \\
\hline 40. & Did your father complain? & 12.06 & .001 \\
\hline 41 . & Did your parents talk over your future? & 11.80 & .01 \\
\hline 42 . & $\begin{array}{l}\text { Did the members of your family openly ex- } \\
\text { press by word or action, their affection } \\
\text { for one another? }\end{array}$ & 23.10 & .001 \\
\hline 43. & $\begin{array}{l}\text { Did your mother attend the school programs } \\
\text { and other school activities in which you } \\
\text { took part? }\end{array}$ & -6.40 & .05 \\
\hline 44. & $\begin{array}{l}\text { Was your mother at home when you got home } \\
\text { from school? }\end{array}$ & 5.38 & n.s. \\
\hline 45. & $\begin{array}{l}\text { Did you seem to get scolded for every little } \\
\text { thing? }\end{array}$ & 20.86 & .001 \\
\hline 46. & $\begin{array}{l}\text { Did your parents allow you to "act your } \\
\text { age"? }\end{array}$ & 18.75 & .001 \\
\hline 47. & $\begin{array}{l}\text { Where your affairs were concerned, did } \\
\text { you think "What my folks don't know won't } \\
\text { hurt them"? }\end{array}$ & 16.57 & .001 \\
\hline 48. & $\begin{array}{l}\text { Did other young people seem to have more fun } \\
\text { with their families than you did with yours? }\end{array}$ & 31.66 & .001 \\
\hline 49. & $\begin{array}{l}\text { Would your parents have made fun of you if } \\
\text { you had told them about your pet peeves? }\end{array}$ & 15.29 & .001 \\
\hline
\end{tabular}


TABLE II (CONTINUED)

\begin{tabular}{|c|c|c|c|}
\hline & Item & $x^{2}$ & $\begin{array}{l}\text { Level of } \\
\text { Significance }\end{array}$ \\
\hline 50. & $\begin{array}{l}\text { Did your family go on little holiday } \\
\text { trips and picnics together? }\end{array}$ & 11.29 & .01 \\
\hline 51. & $\begin{array}{l}\text { Were you told to keep still when you } \\
\text { tried to argue with your father? }\end{array}$ & 21.88 & .001 \\
\hline $52 。$ & $\begin{array}{l}\text { Were you told to keep still when you } \\
\text { tried to argue with your mother? }\end{array}$ & 13.32 & .01 \\
\hline 53. & $\begin{array}{l}\text { Did your parents make fun of your mis- } \\
\text { takes? }\end{array}$ & 9.76 & .01 \\
\hline 54. & $\begin{array}{l}\text { Did they help you to overcome your mis- } \\
\text { takes? }\end{array}$ & 22.69 & .001 \\
\hline 55. & Did your parents overlook your mistakes? & 4.51 & n.s. \\
\hline 56. & $\begin{array}{l}\text { When your parents refused to allow you to } \\
\text { to something, did they give you a reason? }\end{array}$ & 25.82 & .001 \\
\hline 57. & $\begin{array}{l}\text { Did you think you deserved the punishment } \\
\text { you got? }\end{array}$ & 16.40 & .001 \\
\hline 58. & $\begin{array}{l}\text { Did every member in your family have "his } \\
\text { say" in what the family did as a group? }\end{array}$ & 13.92 & .001 \\
\hline 59. & Did your family enjoy working together? & 33.43 & .001 \\
\hline 60. & $\begin{array}{l}\text { Were there times when some member of } \\
\text { your family "wouldn't speak" to other } \\
\text { members? }\end{array}$ & 14.34 & .001 \\
\hline 61. & $\begin{array}{l}\text { Did either of your parents disapprove of } \\
\text { your friends? }\end{array}$ & 9.83 & .01 \\
\hline 62. & $\begin{array}{l}\text { Were your friends uncomforatble around } \\
\text { your parents? }\end{array}$ & 16.22 & .001 \\
\hline 63. & $\begin{array}{l}\text { Did other parents seem to like their } \\
\text { children better than yours liked you? }\end{array}$ & 27.75 & .001 \\
\hline 64. & Did you disagree with your mother? & 15.45 & .001 \\
\hline 65. & $\begin{array}{l}\text { Did your parents change their plans to } \\
\text { suit yours? }\end{array}$ & 16.96 & .001 \\
\hline
\end{tabular}


TABLE II (CONTINUED)

\begin{tabular}{|c|c|c|c|}
\hline & Item & $x^{2}$ & $\begin{array}{l}\text { Level of } \\
\text { Significance }\end{array}$ \\
\hline 66. & $\begin{array}{l}\text { Did you have more fun away from home } \\
\text { than at home? }\end{array}$ & 25.60 & .001 \\
\hline 67. & $\begin{array}{l}\text { Did either of your parents do things that } \\
\text { made them appear foolish? }\end{array}$ & 20.22 & .001 \\
\hline 68. & $\begin{array}{l}\text { Did your parents like to have your } \\
\text { friends around? }\end{array}$ & 17.33 & .001 \\
\hline 69 . & $\begin{array}{l}\text { Did your family have good times together } \\
\text { at home? }\end{array}$ & 37.94 & .001 \\
\hline 70. & $\begin{array}{l}\text { Did you think your parents were } \\
\text { stingy in not giving you more } \\
\text { spending money? }\end{array}$ & 11.73 & .01 \\
\hline 71. & $\begin{array}{l}\text { When you asked your mother why you must } \\
\text { do a certain thing, did she say, "be- } \\
\text { cause I told you to"? }\end{array}$ & 15.71 & .001 \\
\hline 72 . & $\begin{array}{l}\text { Did you get disgusted with the way your } \\
\text { father acted in public? }\end{array}$ & 17.65 & .001 \\
\hline 73. & $\begin{array}{l}\text { Did you get disgusted with the way your } \\
\text { mother acted in public? }\end{array}$ & 5.70 & n.s. \\
\hline 74. & $\begin{array}{l}\text { Did you go to shows, parties, or enter- } \\
\text { tainments together as a family group? }\end{array}$ & 20.42 & .001 \\
\hline 75 . & $\begin{array}{l}\text { Did you think that either of your parents } \\
\text { held grudges against you? }\end{array}$ & 0.01 & n.s. \\
\hline 76. & $\begin{array}{l}\text { Did you like to spend long winter evenings } \\
\text { with your family group? }\end{array}$ & 30.44 & .001 \\
\hline 77. & Did your mother nag and scold? & 9.11 & .05 \\
\hline 78. & Did your father nag and scold? & 24.26 & .001 \\
\hline 79 . & $\begin{array}{l}\text { Did you celebrate the birthdays in your } \\
\text { family? }\end{array}$ & 13.55 & .01 \\
\hline 80 . & $\begin{array}{l}\text { When you were in trouble, could you } \\
\text { depend upon your parents being loyal to } \\
\text { you? }\end{array}$ & 16.22 & .001 \\
\hline
\end{tabular}


Table III describes the responses of the male college students participating in the study to each item on Stott!'s Home Life Scale. The choice of response determined how the subject perceived his home life when he was in high school. Each item was analyzed according to the percentage of positive, average, and negative perceptions of home life and is presented in Table III.

Each participant responded to the statements as they pertained to his home life. The choices which the subjects were given were "Frequently", "Occasionally", and "Rarely." A key for the responses is shown in Appendix C. The most desirable answer was given a score of two which corresponds with the "positive" rating in Table III. Similarly, the "average" would correspond to the one in the scoring key and zero would correspond to the "negative" rating.

Forty-one of the eighty questions had the highest percentage of responses in the positive range. This shows an overall favorable feeling toward the subjects' family or orientation. An interesting trend can be noted when questions were asked directly about the mother-son versus father-son relationship. For example, "Was your mother a good sport?" and "Did you feel your mother liked you?" received the smallest percentage, $0.93 \%$, of negative responses and the second question received the highest percentage of positive responses. In contrast, when the question "Do you feel your father liked you?" was asked, 1.85 percent responded negatively. This would tend to support Hawkes' (1957) thesis that children perceive their mothers more favorably than their fathers. Rose (1959) however, found that both men and women were more willing to express fondness for mothers than for fathers which leads to another possible explanation for this outcome. Another area of consideration 
TABLE III

RESPONSES OF UNIVERSITY MEN TO THE HOME LIFE SCALE

\begin{tabular}{|c|c|c|c|c|}
\hline \multirow{2}{*}{\multicolumn{2}{|c|}{ Item }} & \multicolumn{3}{|c|}{ Percentage } \\
\hline & & Positve & Average & Negative \\
\hline 1. & $\begin{array}{l}\text { Was meal time a happy time in your } \\
\text { family? }\end{array}$ & 67.59 & $29: 63$ & 2.78 \\
\hline 2 . & $\begin{array}{l}\text { Do the members of your family enjoy } \\
\text { hobbies? }\end{array}$ & 37.04 & 49.07 & 13.89 \\
\hline 3. & $\begin{array}{l}\text { Are birthdays special days in your } \\
\text { family? }\end{array}$ & 63.89 & 26.85 & 9.26 \\
\hline 4. & $\begin{array}{l}\text { Did your father attend the school pro- } \\
\text { grams and other school activities in } \\
\text { which you took part? }\end{array}$ & 50.93 & 31.48 & 17.59 \\
\hline 5. & $\begin{array}{l}\text { Was your family breakfast a gloomy } \\
\text { affair? }\end{array}$ & 47,22 & 43.52 & 9.26 \\
\hline 6. & Was your father a good sport? & 72.22 & 23.15 & 4.63 \\
\hline 7. & Was your mother a good sprot? & 76.85 & 22.2 & 0.93 \\
\hline 8. & $\begin{array}{l}\text { Did it seem as if your family treated } \\
\text { you like a child? }\end{array}$ & 34.26 & 49.07 & 16.67 \\
\hline 9. & $\begin{array}{l}\text { Did your family talk over future plans } \\
\text { together? }\end{array}$ & 39.81 & 40.74 & 19.44 \\
\hline 10. & $\begin{array}{l}\text { Did your parents listen to your side } \\
\text { when you disagreed with them? }\end{array}$ & 36.48 & 54.63 & 8.33 \\
\hline 11. & $\begin{array}{l}\text { Did your parents ever admit they had } \\
\text { been wrong? }\end{array}$ & 15.74 & 67.59 & 16.67 \\
\hline 12. & Did you "talk back" to your father? & 55.56 & 37.96 & 6.48 \\
\hline 13. & Did you "talk back" to your mother? & 29.63 & 54.63 & 15.74 \\
\hline 14. & $\begin{array}{l}\text { Did your parents stay home because they } \\
\text { had so much work to do? }\end{array}$ & 32.41 & 49.07 & 18.52 \\
\hline 15. & $\begin{array}{l}\text { Did you leave the place without telling } \\
\text { anyone where you were going? }\end{array}$ & 43.52 & 37.96 & 18.52 \\
\hline 16. & $\begin{array}{l}\text { Did you hesitate to talk frankly with } \\
\text { your father about personal problems? }\end{array}$ & 24.07 & 37.04 & 38.89 \\
\hline
\end{tabular}




\begin{tabular}{c|l}
\hline Item & P \\
\hline
\end{tabular}

17. Did you like to do extra little things $21.30 \quad 67.59 \quad 11.11$ to please the members of your family?

18. Would you have been more proud of your $\begin{array}{llll}58.33 & 24.07 & 17.59\end{array}$ father if he had changed some of his ways?

$\begin{array}{lllll}\text { 19. Would you have been more proud of your } & 54.63 & 38.89 & 6.48\end{array}$ mother if she would have changed some of her ways?

20. Did your mother like to listen to what $69.44 \quad 26.85 \quad 3.70$ you told her when you got home from school?

21. Did your father resent it when you dis- $35.19 \quad 46.30 \quad 18.52$ agreed with him.

22. Did your mother resent it when you disagreed with her?

23. Did you have "a say" as to how and where the family spent its holidays?

24. Did you think "Oh what is the use!" after you had tried to explain your conduct to your parents?

$\begin{array}{lllll}25 . & \text { Did you think your mother gave pretty } & 53.70 & 43.52 & 2.78\end{array}$ sound advice?

26. Did you think your father gave pretty $\quad \begin{array}{lll}71.30 & 24.07 & 4.63\end{array}$ sound advice?

27. Did you try out what your parents advised?

28. Did you turn down chances to go out with others in order to keep your appointment to do something with your family?

$\begin{array}{lll}33.33 & 54.63 \quad 12.04\end{array}$

$22.22 \quad 48.15 \quad 29.63$

$16.67 \quad 61.11 \quad 22.22$

48.15 $\quad 48.15 \quad 3.70$

$12.04 \quad 66.67 \quad 21.30$

29. Did you feel that your mother liked you?

$92.59 \quad 6.48 \quad 0.93$

30. Did you feel that your father liked $\quad \begin{array}{llll}85.19 & 12.96 & 1.85\end{array}$ you? 


\begin{tabular}{c|l|l|l}
\hline \multirow{2}{*}{ Item } & \multicolumn{2}{|c}{ Percentage } \\
\cline { 2 - 3 } & Positive & Average & Negative \\
\hline
\end{tabular}

31. When you went to another town, did you $22.22 \quad 47.22 \quad 30.56$ buy souvenirs or gifts for persons in your family?

32. Did either of your parents read your personal mail without your permission?

33. Did you let your parents in on your "big moments"?

$82.41 \quad 10.19 \quad 7.41$

$61.11 \quad 28.70 \quad 10.19$

$51.85 \quad 37.04 \quad 11.11$

34. Did your feel rebellious around your family?

35. Did you get your information on sex from your parents?

36. Was your father too busy to pay any attention to the family?

37. Did you think your family picked on you?

38. Did you enjoy being shut in with your family on a stormy day?

39. Did your parents trust you to behave when you were away from them?

40. Did your father complain?

41. Did your parents talk over your future?

42. Did the members of your family openly express by word or action, their affection for one another?

43. Did your mother attend the school programs and other school activities in which you took part?

44. Was your mother at home when you got home from school?

45. Did you seem to get scolded for every little thing? $\begin{array}{lll}53.70 & 36.11 & 10.19\end{array}$

42.59

48.15

9.26

$11.11 .33 .33 \quad 55.56$

$\begin{array}{lll}70.37 & 24.07 & 5.56\end{array}$

$\begin{array}{lll}70.37 & 24.07 & 5.56\end{array}$

$19.44 \quad 49.07 \quad 31.48$

$84.26 \quad 11.11 \quad 4.63$

$\begin{array}{lll}35.19 & 37.96 & 26.85\end{array}$

$58.33 \cdot 31.48 \quad 10.19$

$56.48 \quad 14.81 \cdot 28.70$

$60.19 \quad 34.26 \quad 5.56$ 
TABLE III (CONTINUED)

\begin{tabular}{|c|c|c|c|c|}
\hline \multirow{2}{*}{\multicolumn{2}{|c|}{ Item }} & \multicolumn{3}{|c|}{ Percentage } \\
\hline & & Positive & Average & Negative \\
\hline 46. & $\begin{array}{l}\text { Did your parents allow you to "act } \\
\text { your age"? }\end{array}$ & 67.59 & 25.93 & 6.48 \\
\hline 47. & $\begin{array}{l}\text { Where your affairs were concerned, } \\
\text { did you think "What my folks don't } \\
\text { know won! t hurt them"? }\end{array}$ & 17.59 & 66.67 & 15.74 \\
\hline 48. & $\begin{array}{l}\text { Did other young people seem to have } \\
\text { more fun with their families than you } \\
\text { did with yours? }\end{array}$ & 35.19 & 49.07 & 15.74 \\
\hline 49. & $\begin{array}{l}\text { Would your parents have made fun of } \\
\text { you if you had told them about your } \\
\text { pet peeves? }\end{array}$ & 67.59 & 26.85 & 5.56 \\
\hline 50. & $\begin{array}{l}\text { Did your family go on little holiday } \\
\text { trips and picnics together? }\end{array}$ & 31.48 & 41.67 & 26.85 \\
\hline 51. & $\begin{array}{l}\text { Were you told to keep still when you } \\
\text { tried to argue with your father? }\end{array}$ & 44.44 & 37.96 & 17.59 \\
\hline 52. & $\begin{array}{l}\text { Were you told to keep still when you } \\
\text { tried to argue with your mother? }\end{array}$ & 42.59 & 42.59 & 14.81 \\
\hline 53. & $\begin{array}{l}\text { Did your parents make fun of your } \\
\text { mistakes? }\end{array}$ & 78.70 & 16.67 & 4.63 \\
\hline 54. & $\begin{array}{l}\text { Did they help you to overcome your } \\
\text { mistakes? }\end{array}$ & 58.33 & 33.33 & 8.33 \\
\hline 55. & $\begin{array}{l}\text { Did your parents overlook your } \\
\text { mistakes? }\end{array}$ & 18.52 & 52.78 & 28.70 \\
\hline 56. & $\begin{array}{l}\text { When your parents refused to allow } \\
\text { you to do something, did they give } \\
\text { you a reason? }\end{array}$ & 46.30 & 39.81 & 13.89 \\
\hline 57. & $\begin{array}{l}\text { Did you think you deserved the } \\
\text { punishment you got? }\end{array}$ & 35.19 & 56.48 & 8.33 \\
\hline 58. & $\begin{array}{l}\text { Did every member in your family } \\
\text { have "his say" in what the family } \\
\text { did as a group?. }\end{array}$ & 41.67 & 45.37 & 12.96 \\
\hline 59. & $\begin{array}{l}\text { Did your family enjoy working } \\
\text { together? }\end{array}$ & 33.33 & 56.48 & 10.19 \\
\hline
\end{tabular}


TABLE III (CONTINUED)

\begin{tabular}{|c|c|c|c|c|}
\hline \multirow{2}{*}{\multicolumn{2}{|c|}{ Item }} & \multicolumn{3}{|c|}{ Percentage } \\
\hline & & Positive & Average & Negative \\
\hline 60 . & $\begin{array}{l}\text { Were there times when some member of } \\
\text { your family "wouldn't speak" to } \\
\text { other members? }\end{array}$ & 45.37 & 48.15 & 6.48 \\
\hline 61. & $\begin{array}{l}\text { Did either of your parents disapprove } \\
\text { of your friends? }\end{array}$ & 47.22 & 42.59 & 10.19 \\
\hline 62. & $\begin{array}{l}\text { Were your friends uncomfortable } \\
\text { around your parents? }\end{array}$ & 74.07 & 16.67 & 9.26 \\
\hline 63. & $\begin{array}{l}\text { Did other parents seem to like their } \\
\text { children better than yours liked you? }\end{array}$ & 72.22 & 22.22 & 5.56 \\
\hline 64. & Did you disagree with your mother? & 18.52 & 61.11 & 20.37 \\
\hline 65. & $\begin{array}{l}\text { Did your parents change their plans } \\
\text { to suit yours? }\end{array}$ & 7.41 & 63.89 & 28.70 \\
\hline 66. & $\begin{array}{l}\text { Did you have more fun away from } \\
\text { home than at home? }\end{array}$ & 11.11 & 58.33 & 30.56 \\
\hline 67. & $\begin{array}{l}\text { Did either of your parents do things } \\
\text { that made them appear foolish? }\end{array}$ & 56.48 & 40.74 & 2.78 \\
\hline 68. & $\begin{array}{l}\text { Did your parents like to have your } \\
\text { friends around? }\end{array}$ & 51.85 & 41.67 & 6.48 \\
\hline 69. & $\begin{array}{l}\text { Did your family have good times to- } \\
\text { gether at home? }\end{array}$ & 45.37 & 46.30 & 8.33 \\
\hline 70. & $\begin{array}{l}\text { Did you think your parents were } \\
\text { stingy in not giving you more } \\
\text { spending money? }\end{array}$ & 68.22 & 29.91 & 1.87 \\
\hline 71. & $\begin{array}{l}\text { When you asked your mother why you } \\
\text { must do a certain thing, did she say, } \\
\text { "because I told you to"? }\end{array}$ & 27.79 & 50.93 & 21.30 \\
\hline 72. & $\begin{array}{l}\text { Did you get disgusted with the way } \\
\text { your father acted in public? }\end{array}$ & 77.78 & 17.59 & 4.63 \\
\hline 73. & $\begin{array}{l}\text { Did you get disgusted with the way } \\
\text { your mother acted in public? }\end{array}$ & 85.05 & 14.02 & 0.93 \\
\hline
\end{tabular}


TABLE III (CONTINUED)

\begin{tabular}{|c|c|c|c|c|}
\hline \multirow{2}{*}{\multicolumn{2}{|c|}{ Item }} & \multicolumn{3}{|c|}{ Percentage } \\
\hline & & Positive & Average & Negative \\
\hline 74. & $\begin{array}{l}\text { Did you go to shows, parties, or } \\
\text { entertainments together as a family } \\
\text { group? }\end{array}$ & 7.41 & 50.93 & 41.67 \\
\hline 75. & $\begin{array}{l}\text { Did you think that either of your } \\
\text { parents held grudges against you? }\end{array}$ & 87.04 & 11.11 & 1.85 \\
\hline 76. & $\begin{array}{l}\text { Did you like to spend long winter } \\
\text { evenings with your family group? }\end{array}$ & 9.26 & 60.19 & 30.56 \\
\hline 77. & Did your mother nag and scold? & 52.78 & 37.04 & 10.19 \\
\hline 78. & Did your father nag and scold? & 72.77 & 23.15 & 4.63 \\
\hline 79. & $\begin{array}{l}\text { Did you celebrate the birthdays in } \\
\text { your family? }\end{array}$ & 66.67 & 28.70 & 4.63 \\
\hline 80 . & $\begin{array}{l}\text { When you were in trouble, could you } \\
\text { depend upon your parents being loyal } \\
\text { to you? }\end{array}$ & 80.56 & 16.67 & 2.78 \\
\hline
\end{tabular}


is that fathers have more conflict with sons because of their son's unwillingness to accept authorfty (Koch, 1955) and that the conflict with father usually damages his image more than the conflict with mother (Benson, 1968).

\section{Relationship Between Scores and Selected Background Variables}

Responses to the Home Life Scale

Hypothesis 1. There is no slgnificant relationship between perceptions of university men concerning the home life which existed in their families of orientation and: (a) age; (b) marital status of students, (c) father's occupation, (d) father's education, (e) source of family income, and (f) socioeconomic status of parents.

The Mann-Whitney U Test was used to examine scores on the Home Life Scale which were classified in terms of age and marital status. Perceptions of home, life, as reflected by the Home Life Scale were unrelated to these background variables. The results of this analysis are presented in Table IV.

TABLE IV

MANN-WHITNEY U ANALYSIS OF HOME LIFE SCALE SCORES CLASSIFIED BY SELECTED BACKGROUND VARIABLES

\begin{tabular}{lcc}
\hline Background Variable & $\mathrm{U}$ & $\begin{array}{c}\text { Level of } \\
\text { Significance }\end{array}$ \\
\hline Age & -0.838 & n.s. \\
Marital Status & 0.167 & n.s. \\
\hline
\end{tabular}


The Kruskal-Wallis one-way analysis of variance was used to test for the significance of the differences in scores of the students on the Stott's Home Life Scale classified according to: (a) father's occupation, (b) father's education, (c) source of family income, and (d) socioeconomic status of parents. None of these variables were found to be significantly related to the subjects' perceptions of their home life. The results of this analysis are presented in Table $V$.

\section{TABLE V}

KRUSKAL-WALLIS ANALYSIS OF HOME LIFE SCALE SCORES CLASSIFIED BY SELECTED BACKGROUND VARIABLES

\begin{tabular}{lccc}
\hline Background Variables & df & H & $\begin{array}{c}\text { Level of } \\
\text { Significance }\end{array}$ \\
\hline Father's Occupation & 2 & 4.213 & n.s. \\
Father's Education & 2 & 4.353 & n.s. \\
Source of Family Income & 2 & 5.597 & n.s. \\
Socioeconomic Status & 2 & 0.215 & n.s. \\
\hline
\end{tabular}

Hypothesis 2 . There is no significant relationship between attitudes of university men concerning father-son relationships and: (a) age, (b) marital status of students, (c) father's occupation, (d) father's education, (e) source of family income, and (f) socioeconomic status of parents.

The Mann-Whitney U Test was also used to examine scores on the 
Father-Son Interaction Test which were classified in terms of age and marital status. These variables were found not to be significantly related to permissive attitudes as measured by the Father-Son Interaction Test. The results of this analysis are presented in Table VI.

TABLE VI

MANN-WHITNEY U ANALYSIS OF FATHER-SON INTERACTION TEST SCORES CLASSIFIED BY SELECTED BACKGROUND VARIABLES

\begin{tabular}{lcc}
\hline Background Variable & $\mathrm{U}$ & $\begin{array}{c}\text { Level of } \\
\text { Significance }\end{array}$ \\
\hline Age & 1.051 & n.s. \\
Marital Status & 0.151 & n.s. \\
\hline
\end{tabular}

The Kruskal-Wallis one-way analysis of variance was also used to examine scores on the Father-Son Interaction Test which were classified in terms of: (a) father's occupation, (b) father's education, (c) source of family income, and (d) socioeconomic status of parents. None of these variables were found to be'significantly related to permissive attitudes. The results of this analysis are presented in Table.VII.

Hypothesis 3. There is no significant relationship between atti- . tudes of university men concerning father-son relationships and their perceptions concerning the home life which existed in their families of orientation. 
TABLE VII

\begin{tabular}{|c|c|c|c|}
\hline Background Variables & $\mathrm{df}$ & $\mathrm{H}$ & $\begin{array}{c}\text { Level of } \\
\text { Significance }\end{array}$ \\
\hline Father's Occupation & 2 & 2.552 & n.s. \\
\hline Father's Education & 2 & 0.499 & n.s. \\
\hline Source of Family Income & 2 & 2.527 & n.s. \\
\hline Socioeconomic Status & 2 & 1.588 & n.s. \\
\hline
\end{tabular}

A Spearman, $r$ was used to determine the relationship between the responses on the Father-Son Interaction Test and the Home Life Scale. An $r$ of -.22 was obtained suggesting that negative perceptions concerning one's life in his family of orientation were positively related to permissive attitudes on the Father-Son Interaction Test at the .05 leve1 of significance. It is possible that sons who view their own families unfavorably may wish to create in their families of procreation a warmer, less restrictive atmosphere and that this attitude is reflected in the responses which were obtained. 
TABLE VIII

SPEARMAN $\cdot r$ ANALYSIS OF THE FATHER-SON INTERACTION TEST AND THE HOME LIFE SCALE

\begin{tabular}{lccc}
\hline Spearman $r$ & $d f$ & $t$ & Level of Significance \\
\hline-.22 & 106 & -2.32 & .05 \\
\hline
\end{tabular}


CHAPTER V

SUMMARY AND IMPLICATIONS

The purpose of this research was to examine the responses of male university students to the Father-Son Interaction Test and Stott's Home Life Scale in relation to selected background characteristics. To achieve this purpose, a filmed instrument designed to assess permissiveness concerning father-son interaction was used. Stott's Home Life Scale was administered to determine the subjects' perceptions of their home life, and a questionnaire was also used in order to obtain information concerning personal characteristics, socioeconomic status, and family history.

The subjects participating in this study were 108 male college students who were enrolled in the undergraduate course, Home Economics for Men, at Oklahoma State University during the fall semester of 1970 . The majoxity of the subjects ranged in age from 17-22, were single, and came from the middle socioeconomic class.

The Father-Son Interaction Test, a film test developed by Doyle (1968) consists of eleven scenes. The selection of the scenes was made by a panel of specialists who judged each scene according to the following critexia: physical properties, behavioral patterns, theme diversity, and objectivity. The test used was the version of the Father-Son Interaction Test developed by Heath (1970) which was designed especially for male university students. 
The Mann-Whitney U Test revealed that permissive attitudes toward father-son interaction were independent of age and marital status.

The Kruskal-Wallis one-way analysis of variance showed that permissiveness was independent of: (a) father's occupation, (b) father's education, (c) family income; and (d) socioeconomic status.

The Home Life Scale was developed by Stott (1956) to determine the subjects' perceptions of their home life. The 80 item scale was used in collecting the data. An item analysis utilizing the chi-square test revealed that 72 of the 80 items on the Home Life Scale discriminated the responses of the most desirable and least desirable perceptions of the subjects'home life. In order to assess the reliability of the instrument, a split-half technique was utilized and a Spearman $r$ of .94 was obtained.

A Mann-Whitney $U$ test revealed that perceptions of home life were independent of age and marital status.

The Kruskal-Wallis one-way analysis of variance showed that perceptions of home life were independent of: (a) father's occupation, (b) father's education, (c) family income, and (d) socioeconomic status. The Spearman $r$ Correlation Coefficient of -.22 suggested that negative pexceptions of the subjects' home life (measured by the Home Life Scale) were positively related to permissive attitudes on the Fathex-Son Interaction Test at the .05 level of significance.

\section{Implications}

The literature on parent-child relationships emphasizes the influence which parents have on children. In recent years, however, it has become apparent that many persons within the child's life serve as 
models to influence his behavior (Benson, 1968). It seems logical to assume that young people who perceive their home life as being positive, reflecting a close relationship between themselves and their parents, will grow up and reflect warm, permissive attitudes toward parent-child relationships, and that young people who view their family relationships in their families of orientation as harsh, punitive, and without closeness will grow up and view parent-child relationships restrictive1y. However, the evidence from the present investigation suggests a relationship which is not quite so simple in nature. Several things, it is known, alter this relationship. Through formal education, for example, modification in child rearing attitudes takes place (Walters, 1958 and Walters and.Fisher, 1958). More importantly, such findings support the belief that youth are not the victims of a past from which there is no escape. Child rearing is not invariantly related to attitudes concerning children.

From a positive viewpoint, the young men reported that during their youth in high school meal time was a happy time at home, that birthdays were considered special events, that their mothers and fathers were good sports, that their mothers liked to listen to what they had to say when they got home from school, that their mothers and fathers gave them sound advice, that they felt they were liked by their mothers and fathers, that they "let their parents in on big moments," that their fathers were not too busy to pay attention to their families, that they felt their parents trusted them, that their parents allowed them to "act their age," that their parents did not make fun of their mistakes, that their friends were not uncomfortable around their parents, that their parents were not stingy in giving them money, that they were proud of 
their mothers and fathers in public, that their parents did not hold grudges against them, and that when they were in trouble they could depend on their parents to be loyal to them.

Conversely, there were a few negative reports: Over a third hesitated to talk frankly with their fathers about personal problems. Over 55 percent indicated that they rarely got information about sex from their parents. Twenty-eight percent reported that their parents rarely overlooked their mistakes and that their parents rarely changed their plans to suit them. Nearly a third reported that they had more fun away from home than at home and over 40 percent reported that they rarely went, to a show, party, or other entertainment as a family. Attitudes concerning the rearing of children are most certainly modified by the kinds of experience which young people have in their families of orientation as reflected in the relationship obtained in the present study between perceptions of family life and attitudes toward father-son relations. But in a period of rapid change, there is a change in values among youth which is a reflection of a multiplicity of factors: television, school, peers, and neighbors. There is a growing awareness that there is no single way to rear children but that there are a varlety of ways. The mass media have made large numbers of persons aware of an almost inifinte variety of life styles. This may have contributed to the low correlations obtained between the Father-Son Interaction Test and the Home Life Scale, although the correlation was statistically significant. It is possible therefore, that sons who view their own family life negatively may wish to create an atmosphere which is warmer and less restrictive in their.own families of procreation. 


\section{BIBLIOGRAPHY}

Bartemeier, L. "The Contribution of the Father to the Mental Health of the Family." American Journal of Psychiatry, Vo1. 3 (1953), 277280 .

Baumrind, Diana. "Child Care Practices Anteceding Three Patterns of Preschool Behavior." Genetic Psychology Monographs, Vol. 75 (1967), 43-88.

Baumrind, Diana. "Effects of Authoritative Parental Control on Child Behavior.". Child Development, Vol. 38 (1966), 887-907.

Bayley, Nancy. "Research in Child Development: A Longitudinal Perspective." Merrill-Palmer Quarterly of Development and Behavior, Vol. 2 (1965), 183-208.

Becker, Wesley C. and Ronald S. Krug. "A Circumplex Model for Social Behavior in Children." Child Development, Vol. 35 (1964), 371396.

Benson, Leonard. Fatherhood: A Sociological Prespective. New York: Random House, 1968.

Biller, Henry B。 "A Note on Father Absence and Masculine Development in Lower-Class Negro and White Boys." Child Development, Vol. 39 (1968), 1003-1006.

Biller, Henry B. and Lloyd J. Borstelmann. "Masculine Development: An Integrative Review." Merrill-Palmer Quarterly of Development and Behavior, Vol. 13 (1967), 253-294.

Bossaxd, James H. and Eleanor Stoker Boll. The Sociology of Child Development. New York: Harper and Brothers, 1960.

Bronfenbrenner, Urie. "Toward a Theoretical Model for the Analysis of Parent-Child Relationships in a Social Context." In John.Glidewell (ed.), Parental Attitudes and Child Behavior, Conference on Community Mental Health Research, Washington University, St. Louis (1961) 90-109.

Christopher, Samuel A. "Parental Relationship and Value Orientation as Factors in Academic Achievement." Personnel and Guidance Journal, Vol. 45 (1967), 921-925.

Clapp, William F. "Dependence and Competency in Children: Parental Treatment of Four-Year-01d Boys." Dissertation Abstracts, Vol. 28 
(1967), 1703.

Clark, A. W. and Varr Sommers. "Contradictory Demands in Family Relations and Adjustment to School and Home." Human Relations, Vol. 14 (1961), 97-111.

Cross, Herbert J., and Jon.G. Allen. "Relationship Between Memories of Parental Behavior and Academic Achievement in College." Proceedings of the 77th Annual Convention of the American Psychological Association, Vol. 4 (1969), 285-286.

Delaney, Eva J. "Parental Antecedents of Social Aggression in Young Children." Dissertation Abstracts, Vo1. 26 (1965), 1763.

Doyle, Emma Lee. "The Father-Son Interaction Test." Unpublished Ph.D. Thesis, Florida State University, 1968.

E1der, Joseph W. "National Loyalties in a Newly Independent Nation," in David E. Apter (ed.), Ideology and Discontent. New York: Free Press, 1964.

Erikson, Erik H. Young Man Luther. New York: Norton, 1968.

Grandlund, Elnore and Lois Knowles. "Child-Parent Identification and Academic Underachievement." Journal of Consulting and Clinical. Psychology, Vo1. 33 (1969), 495-496.

Hallowitz, David and Burton Stulberg. "The Vicious Cycle in ParentChild Relationship Breakdown." Social Casework, Vol. 40 (1959), 268-275.

Hawkes, Glenn R. "The Child in the Family." Marriage and Family Living, Vol. 19 (1957), 46-51.

Heath, Becky。 "College Students' Perceptions Concerning Father-Son. Interaction." Unpublished M. S. Thesis, Oklahoma State University, 1970。

Hoffman; Martin L. "Personality, Family Structure, and Social Class as Antecedents of Parental Power Assertion." Child Development, Vo1. 34 (1963), 869-884.

Hurlock, Elizabeth B. Child Development. New York: McGraw-Hill Book Company, 1964.

Inkeles, Alex. "Social Change and Social Character: The Role of Parental Mediation," in Neil J. Smelser and William T. Smelser (eds.), Personality and Social Systems. New York: Wiley, 1963.

Johnson, Miriam M。 "Sex Role Learning in the Nuclear Family." Child Development, Vo1. 34 (1963), 319-333。 
Koch, Helen L. "Some Personality Correlates of Sex, Sibling Position and Sex of Siblings Among Five- and Six-Year-0ld Children." Genetic Psychology Monographs, Vol. 52 (1955), 3-50.

Koppitz, E. M。 "Relationships Between Some Background Factors and Children's Interpersonal Attitudes." Journal of Genetic Psychology, Vol。 91 (1957), 119-129.

Lang, Lawrence H. "Responsibility as a Function of Authority in Family Relations." Dissertation Abstracts, Vol. 29 (1969), 3668-3669.

Lefkowitz, Monroe M., Leopold 0. Walder and Leonard Eron. "Punishment, Identification and Aggression." Merrill-Palmer Quarterly of Development and Behavior, Vol。9 (1963), 159-174.

Martin, Cora A. and Alexander L. Clark. "Social Class and Parental Values: A Critical Reappraisal." Paper presented to the Southwestern Sociological Society, New Orleans, 1966.

McGuire C. and C. D. White. "The Measurement of Social Status." Research Paper in Human Development. Austin: University of Texas, (1955) no. 3.

McKeown, James $E$. and Conrad Lhyatte. "The Behavior of Fathers as Reported by Normals, Neurotics, and Schizophrenics." American Catholic Sociological Review, Vol. 15 (1954), 332-340.

Miller, D. R., and G. E. Swanson. Inner Conflict and Defense. New York: Holt-Rinehart and Winston, 1960.

Medinnus, Gene R. "Adolescents Self-Acceptance and Perceptions of Their Parents." Journal of Consulting Psychology, Vol. 29 (1965), 150154 。

Medinnus, Gene R. Readings in Psychology of Parent-Child Relations. New York: Johñ Wiley, 1967.

Mussen, Paul H。 "Some Antecedents and Consequences of Masculine SexTyping in Adolescent Boys." Psychological Monographs, LXXV (1961) no. 2 .

Norris, Nancy P. "Parental Understanding, Parental Satisfaction and Desirable Personality Characteristics in Preadolescent Boys." Dissertation Abstracts, Vol. 28 (1968), 4709-4710.

Nunn, Clyde Z. "Child-Control Through a 'Coalition with God." Child Development, Vo1. 35, (1964), 417-432.

Ostrovsky, Everett S. Father to the Child. New York: G. P. Putnam's Sons, 1959 .

Payne, Donald E. and Paul H. Mussen. "Parent-Child Relations and Father Identification Among Adolescent Boys," Journal of Abnormal and Social Psychology, Vol. 52 (1956), 358-362. 
Peppin, Bruce Hilands. "Parental Understanding, Parental Acceptance and the Self Concept of Children as a Function of Academic Overand Under-Achievement." Dissertation Abstracts, Vo1. 23 (1963), 4422-4423。

Rose, Arnold.M. "Acceptance of Adult Roles and Separation from Family." Marriage and Family Living, Vo1. 21 (1959), 120-126.

Rosen, Bernard C. "Social Class and the Child's Perception of the Parent." "Child Development, Vo1. 35 (1964), 1147-1153.

Schaefer, E. S. and N. Bayley. "Maternal Behavior, Child Behavior and Their Intercorrelations From Infancy Through Adolescence." Monographs of the Society for Research in Child Development, Vol. 28 $(1963), 127$.

Sears, Pauline S. "Child-Rearing Factors Related to Playing the SexTyped.Roles." The American Psychologist, Vo1. 8 (1953), 431.

Sollenberger, R. T. "Some Relationships Between the Urinary Excretion of Male Hormone by Maturing Boys and Their Expressed Interests and Attitudes." Journal of Psychology, Vol. 9 (1940), 179-189.

Sopchak, Andrew L. "Parental 'Identification' and 'Tendency Toward Disorders' as Measured by the MMPI." Journal of Abnormal and Social Psychology, Vol. 47 (1952), 159-163.

Starr, Bernard D。 "Disciplinary Attitudes of Both Parents and Authoritarianism in Their Children." Dissertation Abstracts, Vol. 26 (1965), 3482 .

Stone, C. P. and R. G. Barker. "The Attitudes and Interests of Premenarchial and Postmenarchial Girls." Journal of Genetic Psychology, Vol。 51 (1937), 27-71.

Stott, L. H. "Development of a Scale for the Measurement of Attitude Toward Family Life in Teenage Children." Unpublished Paper, Merrill-Palmer School, Detroit, 1956.

Streckex, Edward A. Their Mother's Sons. Philadelphia: J. B. Lippincot Company, 1946.

Tallman, Irving. "Spousal Role Differentiation and the Socialization of Severely Retarded Children." Journal of Marriage and the Family, Vol。27 (1965), 37-42.

Tasch, Ruth Jacobson. "The Role of the Father in the Family." Journal of Experimental Education, June, 1952.

Tuma, Elias and Norman Livson. "Family Socioeconomic Status and Adolescent Attitudes Toward Authority。" Child Development, Vol。30 (1960), 387-399. 
Walters, James. "The Effects of an Introductory Course in Child Development on the Attitudes of College Women Toward Child Guidance." Journal of Experimental Education. 1958.

Walters, James and Clara Fisher. "Changes in the Attitudes of Young Women Toward Child Guidance Over a Two-Year Period." Journal of Educationa1 Research, Vol. 52, No. 3, November, 1958.

Walters, James and Nick Stinnett. "A Decade Review of Research." Journal of Marriage and the Family. Spring, $197^{\prime}$.

Wylie, Philip. "American Men Are Lousy Fathers." The American Weekly, November 27, 1955. 
APPENDIX A

THE FATHER-SON INTERACTION TEST 


\section{THE - FATHER-SON INTERACTION TEST \\ (Male University Students Form) \\ Emma Lee Doyle}

The statements in this booklet are statements about the behavior which you will see in each scene. After viewing the scene, you are to answer each statement which pertains to that scene. You are to answer each statement in terms of one of four categories:

$\begin{array}{clcc}\text { SA } & \text { MA } & \text { MD } & \text { SD } \\ \text { Strongly } & \text { Mildly } & \text { Mildly } & \text { Strongly } \\ \text { Agree } & \text { Agree } & \text { Disagree } & \text { Disagree }\end{array}$

Your answer to each statement depends on what you see in the film plus what you know generally about father and son behavior. There is no "right" and "wrong" answer. This is a test of your feelings and attitudes about what you see in the film.

Please answer each statement by circling your choice to each statement. Circle only one answer for each statement. Please answer every statement.

\section{SCENE EXAMPLE}

Suppose the scene showed a son who is 14 years old. His father will not allow him to use his shop tools.

1. The son should not be allowed to use his father's SA MA MD SD tools.

2. The father was wrong in not allowing his son to SA,MA MD SD use his tools.

\section{SCENE I}

The father enters the son's bedroom to awaken him. The son moans and turns over; the father calls him several times. The son finally sits up on the side of the bed.

1. The father should have understood the son's dif- SA MA MD SD ficulty in arising. 
2. The father should have realized that his son's

SA MA MD SD reaction was a normal reaction, and he should not have been threatened.

3. The father should have been irritated by the boy's actions.

SA MA MD SD

4. The father should have been more forceful in getting his son out of bed.

SA MA MD SD

5. The father should not have allowed his son to

SA MA MD SD turn over when he called him.

6. The father should be complimented for having given his son this type of help.

SA MA MD SD

7. The father should have shown more concern for SA MA MD SD his son getting enough rest.

\section{SCENE II}

Scene II opens with the father reading the morning newspaper. The son enters the room and asks for his allowance.

8. The father should have given his son the SA MA MD SD money at the first request.

9. The son should not have interrupted his SA MA MD SD father's activities.

10. The father should have shown more attention SA MA MD SD to his son.

11. The father should not have reacted as this SA MA MD SD father did.

12. The father should have given the money, to SA MA MD SD his son the previous night.

13. The father handled the matter satisfactorily. SA MA MD SD

14. The father should not have ignored his son. SA MA MD SD

16. The son should not" have"had to beg for money. SA MA MD SD

17. The father should have responded inmediately SA MA MD SD when his son asked for "his allowance.

SCENE III

Father and son are having lunch together and have to leave home at the same time. The son is eager to share his week-end trip to the beach with his dad. While relating the details of the trip, the son does not eat his meal. The father has been very quiet during the meal, and when 
it is time for both of them to leave, he realizes that the son has not even begun to eat:

18. The father should have been more attentive to. SA MA MD SD the son's conversation.

19. A father should not have had to listen to SA MA MD SD his son this much during mealtime.

20. The son's actions should not have irritated. SA MA MD SD his father.

21. The father and son should have had a closer SA MA MD SD relationship.

22. The son should have been able to feel more comfortable with his father.

SA MA $\cdot \mathrm{MD}-\mathrm{SD}$

23. The father was right in objecting to his son's: SA MA MD SD slowness in eating.

24. The father should not have been so hasty in SA MA MD SD scolding his son.

25. The father should have participated in his SA MA MD SD son's conversation.

26. The son should not have talked so much. SA MA MD SD

27. The son should not have bothered his $S A$ MA MD SD father about such unimportant matters.

28. The father should have shown more affection SA MA MD SD for his son.

29. The father should have shown more interest in his son's activities.

SA MA MD SD

\section{SCENE IV}

The afternoon baseball game is over! The son rushes up to the father, pleased that their team had won and that he had made the winning run. The father asks, "What about that 'pop-up fly' you missed?"

30. The son should be able to expect more SA MA MD SD encouragement from his father.

31. The father should have first mentioned his SA MA MD SD son's winning run.

32. It is a wise father who gives this kind of SA MA MD SD help in directing his son's play activities.

33. The father should have encouraged his son more. SA MA MD SD 
34. The father should have arrived at a better method of guiding his son.

SA MA MD SD

35. The father should have shown more appreciation

SA MA MD SD for his son's achievements.

36. The father was too concerned with his son's

SA MA MD SD mis takes.

37. The father should have shown more concern for his son's feelings than for his achievements.

SA MA MD SD

\section{SCENE V}

Previously, the father has promised that he would give the son a golf lesson. The father forgot his promise and made a date with a friend to play golf. He is reminded by his son of the promise. The scene ends when the father says, "Well, I guess I could call Fred."

38. The son should not have reminded the father SA MA MD SD of his promise.

39. The father should have cancelled his $\quad$ SA MA MD SD appointment with his son.

40. The father should not have forgotten his promise. SA MA MD SD

41. The father should have offered to take his son SA MA MD SD with him.

42. The father should not have offered to call off SA MA MD SD his business date.

43. The father should have told his son that a SA MA MD SD business deal was more important.

44. The father should have felt happy that his son SA MA MD SD wanted to play golf with him.

45. The son should not have expected his father to SA MA MD SD want to play golf with him.

46. The son should have made his own arrangements SA MA MD SD for playing golf.

47. The father should have shown more affection SA MA MD SD for his son.

48. The father should have felt obligated to play SA MA MD SD golf with his son. 


\section{SCENE VI}

The son has been told that he is to rake the leaves to help prepare the lawn for spring cleaning. He has agreed but he is tired. The father insists that the lawn should be raked today. The son is very reluctant, but the father persists.

49. If a son has feelings of resentment, he should SA MA MD SD express his feelings.

59. The father should have "paddled" his son.

SA MA MD SD

51. The father should have allowed his son to rake

SA MA MD SD the leaves at his convenience.

52. Since the father was so persistent, the son's reaction was appropriate.

SA MA MD SD

53. A son needs a lot of help in learning to assume responsibility for the yard.

54. The father was right in being so persistent.

SA MA MD SD

55. A father should not threaten his son.

SA MA MD SD.

56. A father should be able to reason with his son without threatening him.

SA MA MD SD

57. The father should have been more forceful in the beginning.

SA MA MD SD

58. The father should not have become so excited when his son did not obey him.

SA MA MD SD

\section{SCENE VII}

Father and son are dressed for dinner and are in the dining room. The son reaches for a mint on the table and turns over a glass of water.

59. The father should have insisted that his son

SA MA MD SD clean up the table by himself.

60. The father was too lenient with his son.

SA MA MD SD

61. The father should have punished his son for

SA MA $\cdot M D$ SD spilling the water.

62. The father handled the situation satisfactorily. SA MA MD SD

63. The father should be complimented for having helped his son clean up the table: 
APPENDIX B

STOTT'S HOME LIFE SCALE 
Name Age Class in School Sec. Number of Class

DIRECTIONS: The questions below are about yourself and family. Please do not hesitate to answer them honestly and carefully for your answers will be held in the strictest confidence. In answering the questions think of the relationship you had with your parents while you were in high school:

F means "frequently," "usually," "most of the time," "nearly always."

o means "occasionally," "once in a while," "sometimes."

R means "rarely," "very seldom,"! "almost never."

Circle the correct response.

$\mathrm{F} O \mathrm{R}$ 1. Was meal time a happy time in your family?

$\mathrm{F} O \mathrm{R}$ 2. Do the members of your famlly enjoy hobbies?

$\mathrm{F} \quad \mathrm{O} R$ 3. Are birthdays speciál days in your family?

F $0 . R$ 4. Did your father attend the school programs and other school activities in which you took part?

F, O R 5. Was your family breakfast a gloomy affair?

$\mathrm{F} O \mathrm{R}$ 6. Was your, father a good sport?

F $O$ R 7. Was your mother a good sport?

F $0 . R$ 8. Did it seem as if your family treated you like a child?

F $0 . R$ 9. Did your family talk over future plans together?

F 0 R. 10. Did your parents listen to your side when you disagreed with them?

F $0: R$ 11. Did your parents ever admit they had been wrong?

F 0 R 12. Did you "talk back" to your father?

F. O R 13. Did you "talk back": to your mother? 
F 0 R 14. Did your parents stay home because they had so much work to do?

F $0 \quad R$ 15. Did you leave the place without telling anyone where you were going?

F. $O R$ 16. Did you hesitate to talk frankly with your father about personal problems?

F 0 R 17. Did you like to do extra little things to please the members of your family?

F $0, R$ 18. Would you have been more proud of your father if he had changed some of his ways?

F $0 . R$ 19: Would you have been more proud of your mother if she would have changed some of her ways?

F $0 \mathrm{R}$ 20. Did your mother like to listen to what you told her when you got home from school?

$F \quad 0 \quad R$ 21. Did your father resent it when you disagreed with him?

F $0 . R$ 22. Did your mother resent it when you: disagreed with her?

$F \quad 0 . R$ 23, Did you have "a say" as to how and where the family spent its holidays?

F $O \mathrm{R}$ 24. Did you think "Oh what is the use!" after you had tried to explain your conduct to your parents?

F 0 R 25. Did you think your mother gave pretty sound advice?

F $0 \quad R$ 26. Did you think your father gave pretty sound advice?

F 0 R 27. Did you try out what your parents advised?

F $0 . \mathrm{R}$ 28. Did you turn down chances to go out with others in order to keep your appointment to do something with your family?

F O R 29. Did you feel that your mother liked you?

F 0 R 30. Did you feel that your father liked you?

F 0 R 31.- When you went to another town, did you buy souvenirs or gifts for persons in your family?

F. 0 k 32. Did either of your parents read your personal mail without your permission?

F. O R 33. Did you tet your parents in on your "big moments?"

$\mathrm{F}$ : $\mathrm{R}$ 34. Did you feel rebellious around your family? 
F $0 \mathrm{R}$ 35. Did you get your information on sex from your parents?

F $0 \mathrm{R}$ 36. Was your father too busy to pay any attention to the family?

F : 0 R 37. Did you think your family picked on you?

$F \quad 0 \quad R$ 38. Did you enfoy being shut in with your family as on a stormy day?

F $0: R$ 39. Did your parents trust you to behave when you were away from them?

F $0: R$ 40. Did your father complain?

F 0 R 41. Did your parents and you talk over your future?

F. O R 42. Did the members of your family openly express by word or action, their affection for one another?

F $0: R$ 43. Did your mother attend the school, programs and other school activities in which you took part?

F 0 R 44. Was your mother at home when you got home from school?

F 0 R 45. Did you seem to get scolded for every little thing?

F. O R 46. Did your parents allow you to "act your age"?

$\mathrm{F} O \mathrm{R}$ 47. Where your affairs were concerned, did you think "what my folks don't know won't hurt them"?

F $0 \quad \mathrm{R}$ 48. Did other young people seem to have more fun with their families than you did with yours?

F $0 \quad R$ 49. Would your parents have made fun of you if you had told them about your pet peeves?

F 0 R 50. Did your family go on little holiday trips and picnics together?

F $0 \mathrm{R}$ 51. Were you told to keep still when you tried to argue with your father?

F O R 52. Were you told to keep still when you tried to argue with your mother?

F O R 53. Did your parents. make fun of your mistakes?

F. O R 54. Did they help you to overcome your mistakes?

F 0 R 55. Did your parents overlook, your mistakes? 
F O R 56. When your parents refused to allow you to do something, did they give you a reason?

F : O R 57: Did you think you deserved the punishment you got?

F. $0 \quad R$ 58. Did every member of your family have "his say" in what the family did as a group?

$F: 0 \quad R$ 59. Did your family enjoy working together?

F $0, R$ 60. Were there times when some member of your family wouldn't speak' to other members?

F $0 . R$ 61. Did either of your parents disapprove of your friends?

F 0 R 62. Were your friends uncomfortable around your parents?

$\mathrm{F} O \mathrm{R}$ 63. Did other parents seem to like their children better than yours liked you?

F 0 R 64. Did you disagree with your mother?

$\mathrm{F} O \mathrm{R}$ 65. Did your parents change their plans to suit yours?

F $0 \cdot R$ 66. Did you have more fun away from home than at home?

F $0 \cdot R$ 67. Did either of your parents do things that made them appear foolish?

$\mathrm{F} O \mathrm{R}$ 68. Did your parents like to have your friends around?

F 0 R 69. Did your family have good times together at home?

$\mathrm{F} \quad \mathrm{O} \cdot \mathrm{R}$ 70. Did you think your parents were stingy in not giving you more spending money?

F 0 R 71. When you asked your mother why you must do a certain thing, did she say, "Because I told you to"?

F $0 \quad R$ 72. Did you get disgusted with the way your father acted in public?

F $O \quad R$ 73. Did you get disgusted with the way your mother acted in public?

F. 0 R 74. Did you go to shows, parties, or entertainments together as a family group?

F 0 R 75. Did you think that either of your parents held grudges against you?

F 0 R 76. Did you like to spemd long winter evenings with your family group? 
F 0 R 77. Did your mother nag and scold?

F $0 \quad R$ 78. Did your father nag and scold?

F $0 \mathrm{R}$ 79. Did you celebrate the birthdays in your family?

F $0 \mathrm{R}$ 80. When you were in trouble, could you depend upon your parents being loyal to you? 
APPENDIX C

KEY FOR THE STOTT'S HOME LIFE SCALE 
KEY FOR THE STOTT'S HOME LIFE SCALE

$\begin{array}{llllllllllll}\text { 1. } & 2 & 1 & 0 & 24 . & 0 & 1 & 2 & 47 . & 0 & 1 & 2 \\ \text { 2. } & 2 & 1 & 0 & 25 . & 2 & 1 & 0 & 48 . & 0 & 1 & 2 \\ \text { 3. } & 2 & 1 & 0 & 26 . & 2 & 1 & 0 & 49 . & 0 & 1 & 2 \\ \text { 4. } & 2 & 1 & 0 & 27 . & 2 & 1 & 0 & 50 . & 2 & 1 & 0 \\ \text { 5. } & 0 & 1 & 2 & 28 . & 2 & 1 & 0 & 51 . & 0 & 1 & 2 \\ \text { 6. } & 2 & 1 & 0 & 29 . & 2 & 1 & 0 & 52 . & 0 & 1 & 2 \\ \text { 7. } & 2 & 1 & 0 & 30 . & 2 & 1 & 0 & 53 . & 0 & 1 & 2 \\ \text { 8. } & 0 & 1 & 2 & 31 . & 2 & 1 & 0 & 54 . & 2 & 1 & 0 \\ \text { 9. } & 2 & 1 & 0 & 32 . & 0 & 1 & 2 & 55 . & 2 & 1 & 0 \\ \text { 10. } & 2 & 1 & 0 & 33 . & 2 & 1 & 0 & 56 . & 2 & 1 & 0 \\ \text { 11. } & 2 & 1 & 0 & 34 . & 0 & 1 & 2 & 57 . & 2 & 1 & 0 \\ \text { 12. } & 0 & 1 & 2 & 35 . & 2 & 1 & 0 & 58 . & 2 & 1 & 0 \\ \text { 13. } & 0 & 1 & 2 & 36 . & 0 & 1 & 2 & 59 . & 2 & 1 & 0 \\ \text { 14. } & 0 & 1 & 2 & 37 . & 0 & 1 & 2 & 60 . & 0 & 1 & 2 \\ \text { 15. } & 0 & 1 & 2 & 38 . & 2 & 1 & 0 & 61 . & 0 & 1 & 2 \\ \text { 16. } & 0 & 1 & 2 & 39 . & 2 & 1 & 0 & 62 . & 0 & 1 & 2 \\ \text { 17. } & 2 & 1 & 0 & 40 . & 0 & 1 & 2 & 63 . & 0 & 1 & 2 \\ \text { 18. } & 0 & 1 & 2 & 41 . & 2 & 1 & 0 & 64 . & 0 & 1 & 2 \\ \text { 19. } & 0 & 1 & 2 & 42 . & 2 & 1 & 0 & 65 . & 2 & 1 & 0 \\ \text { 20. } & 2 & 1 & 0 & 43 . & 2 & 1 & 0 & 66 . & 0 & 1 & 2 \\ \text { 21. } & 0 & 1 & 2 & 44 . & 2 & 1 & 0 & 67 . & 0 & 1 & 2 \\ \text { 22. } & 0 & 1 & 2 & 45 . & 0 & 1 & 2 & 68 . & 2 & 1 & 0 \\ \text { 23. } & 2 & 1 & 0 & 46 . & 2 & 1 & 0 & 69 . & 2 & 1 & 0\end{array}$


70. $0 \quad 1 \quad 2$

71. $0 \quad 1 \quad 2$

72. $0 \quad 1 \quad 2$

73. $0 \quad 1 \quad 2$

74. $2 \quad 1 \quad 0$

75. $0 \quad 1 \quad 2$

76. $2 \quad 1 \quad 0$

77. $0 \quad 1 \quad 2$

78. 0.12

79. 210

80. 2110 
APPENDIX D

INFORMATION SHEET 
Oklahoma State University

Division of Home Economics
Department of Family Relationssand Child Development

\section{INFORMATION SHEET}

Please answer the following questions as accurately as you can. It is important that you answer ALL questions which are appropriate. Your identity and your answers will be kept strictly confidential. Your cooperation in this research project is greatly appreciated.

1. Name Sec: No. of class

2. Major

3. Age:

under 20

4. Marital Status:

$20-24$

Single

25 and over

Married Divorced

Separated

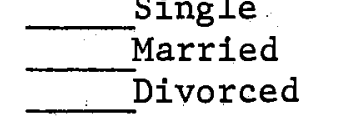

Widowed

7. Were you born in America? Yes No

8. Describe in detail your father's occupation

9. In schoo1, your father completed grades:

$\begin{aligned} \text { none } & \text { graduated from high school } \\ 1-4 & \text { completed } 1-3 \text { years college } \\ 5-7 & \text { graduated from a 4-year college } \\ 8 & \text { over } 4 \text { years of college }\end{aligned}$

10. If you lived on a farm, rate your father's occupation below: Gentleman farmer or landowner who does not directly supervise his property. Land operator who supervises his property and has an active urban life. Farm owner with "hired help," or an operator of leased property who supervises. Small landowner; or an operator of rented property hiring "hands."

Tenant on a good farm; or a foreman or an owner of a farm who "hires out." Sharecropper; or an established farm laborer; or a subsistence farmer. Migrant worker, or a "squatter," or a "nester."

11. The main source of my family's income: wages, hourly wages, piece work, weekly checks salary, monthly checks profits and fees from a business or profession 
savings and investments earned by my father and mother inherited savings and investment

private relief, odd jobs, share cropping, seasonal work public relief or charity 


\author{
VITA \\ Donna Brown Graves \\ Candidate for the Degree of \\ Master of Science
}

Thesis: RELATIONSHIP BETWEEN PERCEPTIONS OF FAMILY IIFE AND ATTITUDES CONCERNING FATHER-SON INTERACTION

Major Field: Family Relations and Child Development

Biographical:

Personal Data: Born in Boston, Massachusetts, March 28, 1946, the daughter of Mr. and Mrs. Donald W. Brown. Married Toby R. Graves, July 23, 1966.

Education: Attended grade school in Karachi, Pakistan; junior high school in Stillwater, Oklahoma; graduated from Stillwater High School in 1964; received the Bachelor of Science Degree from Oklahoma State University, Stillwater, Oklahoma with a major in Family Relations and Child Development in May, 1969; completed requirements for the Master of Science Degree in July, 1971.

Professional Experience: Elementary School Teacher - 6th grade science and social studies, Perry Elementary School, Perry, Oklahoma, 1969-70.

Professional Organizations: National Council of Family Relations and Oklahoma Education Association. 